\title{
PERE DE FOUCAULD AND THE CONVERSION OF ISLAM
}

7 PHAT the ways of God are not men's ways is very clear all through the life of the Père de Foucauld.* It is singularly fortunate that this Saint of modern days should have M. René Bazin as his biographer. The skill in portraiture that he wields as a novelist, his sure and sympathetic touch are all needed to make a material world realise the deep and far-reaching import of Charles de Foucauld's vocation.

Its chief characteristic was patient, faithful, waiting on the will of God. He knew from the first moment of his conversion that he had a destiny to accomplish. His own will was utterly subjected to this destiny, this purpose of God, and his sanctity grew in patient, steady labour in utter loneliness in the wide Sahara for its accomplishment. He has paved the way for a new impulse in the French nation for the conversion of the portion of Islam over which they rule.

The life and martyrdom of the Père de Foucauld is a protest against the attitude almost generally accepted that the Mussulman is unconvertable. This opinion has become a maxim-a stereotyped view. Hilaire Belloc, in his Esto Perpetua, a book of Algerian studies, says, speaking of Islam :

- Against this vast permanent and rooted influence we have nothing to offer. Our designs of material benefit or of positive enlightenment are, to the presence of this common creed as is some human machine to the sea. We can pass through it but we cannot occupy it. It spreads out before our advance, it closes up behind. Nor will our work be accomplished until we have recovered, perhaps

* Charles de Foucauld, by René Bazin. (Plon Nourrit et Cie, Paris). 


\section{Blachfriars}

through disasters suffered in our European homes, the full tradition of our philosophy and a faith which shall permeate all our actions as completely as does this faith of theirs.'

This passage, written eighteen years ago, reads today like a prophecy. Have not the French suffered those disasters in their own homes in the Great War, and has not their faith received new vigour from their sufferings?

Mohammedanism is rooted in ignorance-it melts before education, but gives place to a profound philosophical scepticism in the educated man that is as impervious to the Christian idea as fanatical Islamism. The idea of sacrifice, of repentance and atonement are utterly alien to the educated Mussulman. There is no appeal to his moral sense or to any sense of sin. The uneducated Mussulman, on the other hand, still feels himself vastly superior to the rest of the world. He cares nothing for scientific progress, all that civilization shows him of mechanical discoveries, electricity, railways, aeroplanes, impresses him not in the least. The world went on quite well without them in the days when Islam so nearly conquered the world. To the vast majority, the ignorant and uneducated, these are worked by Christian devils, and they will have none of them. 'The world is yours,' they say, 'but the heavens are ours, because we believe.'

Civilization withers at the touch of Islam. The great Roman civilization of the early centuries was swallowed up by it as by the sands of the desert. Its rigid sterility is its strength, but must in the end be its destruction.

Conversion on a large scale and by usual methods is clearly impossible. The Mussulman has a certain intellectual hold on his faith, and Christianity is not to him the release from the terrors of devil worship. that it is to the negro of Central Africa. MissionI 98 


\section{Père de Foucauld and the Conversion of Islam}

aries reap such rich harvests of souls in these fields it is no wonder they give their labours there rather than to Islam, where results can hardly be seen.

The Père de Foucauld saw that new methods and a new impulse must be created in missionary effort for Christianity to be brought to the Sahara. Words or preaching could no more avail to give the message of that evangelization to a modern material world than they could avail to evangelize the Sahara itself. His life and his death must convey the message, his patient hidden labours must pave the way for others to follow him.

Let us see what that life was, and what it urges for the conversion of Islam.

Charles de Foucauld was not always a saint. He was born at Strasburg of a noble family-the name dates back to 970-and amongst his ancestors was a Bertrand de Foucauld, who went to the crusades with Saint Louis. His parents died when he was six, and the boy lost a mother who would have brought him up piously and wisely. His grandfather, who took over the charge of the two children, Charles and his sister Marie, after their parents' death, admics that he spoilt the boy and failed to teach him to direct his strong will to the correction of his faults rather than to the indulgence of his passionate and indolent nature. 'Men have seldom,' says M. Bazin, 'that intense devotion to the early education of children, nor that gift of instinct by which a mother is warned and put on her guard in time to correct her children's faults.'

Charles de Foucauld wrote later in life a long letter to his brother-in-law, imploring him to give a Catholic education to his sister Marie's two little boys, his nephews. 'If you knew what a difference it would have made to me,' he cries. To be thrown, as he was, a spoilt child already, into the laicized lycée of Nancy 


\section{Blackfriars}

where his grandfather lived, was to abandon him to all bad tendencies that might be in him. He tells his brother-in-law that a Catholic education answers all those questionings and temptations, both intellectual and sensual, which an intelligent and artistic boy finds in himself as he develops.

He managed to scrape into and through St. Cyr after having been expelled from a school previously for idling, and in 1878 he passed into the School of Cavalry at Saumur. Here for two years he and a friend shared a room and a life of brilliant dissipation -dinners, cards, debts, extravagance-and then the regiment, the 4th Hussars, was sent to Africa. At once he got into trouble for his dissipated ways, and was told by his colonel that he must either give them up and a certain liaison he had formed, or leave the regiment. Charles, rebellious to discipline, actually left the regiment and retired on half-pay. But a year

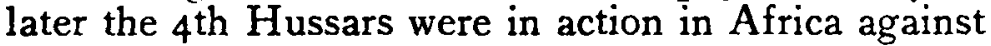
a tribe fanatically in arms for Islam, and de Foucauld threw himself into the campaign and became an enthusiastic soldier, endearing himself to his men and rejecting his luxurious habits.

He had seized the idea of sacrifice, and all the nobility of his character responded.

At once the desert fascinated him, and the passion of the explorer took hold of him. After two years' careful study of Arabic and of the life of the Arab tribes of the Sahara, he laid his plans for the exploration of Morocco.

Disguise was necessary; it was useless to attempt the task as an European. He chose that of a poor Jew as the easiest to live up to. His scientific observations must all be done in complete secrecy; as a Jew he could pretend to be praying on the roof in a solitude in which he could make his observations and write his notes. 


\section{Père de Foucauld and the Conversion of Islam}

His own account of his journey must be read to grasp the determination, the self-sacrifice and devotion that made his journey possible and so valuable in its scientific results. An English scientist writes of this exploration of the young Viconte de Foucauld as ' the most important and valuable journey that any European has carried out in Morocco for the last century or more. No modern traveller can compare with M. de Foucauld in the precision of his observations, and beside his achievements the attempts of other explorers of this country are child's play.'

In his journeyings in the desert he learnt to love solitude and austerity of life. In the desert he could look on as a spectator at the world where "Time like a pulse shakes fierce.' Time and space both receded and God's Voice could make itself heard.

He had been profoundly moved during his life in the Sahara by the Mohammedan's perpetual invocation of God. The calls to prayer, the Arab prostrated five times a day in prayer towards Mecca, the name of Allah always present in their speech and writings, all the religious setting of the Mussulman's life, led him to ask himself, "Why have I no religion?'

At this point it is impossible not to recall another conversion in the desert of a young French officer, that of Ernest Psichari. His book, Le Voyage du Centurion, giving his own account of it, is known to English readers in translation as $A$ Soldier's Pilgrimage.

It was the turning point in his conversion, as in Charles de Foucauld's, when he realised the moral inferiority of his unbelief beside the faith of the Mohammedans.

Gradually it dawned on him how infinitely higher, fuller, deeper was the Christian message than the sterile creed of Islam. 'The will of the Koran ver2OI 


\section{Blachfriats}

sus the Blood of the Martyrs' is the text on which his meditations in the desert run.

The conversions of these two young Frenchmen taken together make up a grand drama. Psichari's intellectual travail, the silence of the desert, letting the voice of God be heard, led him back to the Church from which his grandfather, Ernest Renan, had apostatized. Subsequent biographies tell us that after his submission he desired the complete immolation of himself as a Dominican. But this was anticipated by his death as a soldier in the Great War. Who knows that as a priest he might not have devoted himself to the conversion of Islam and preached the Catholic faith in the desert that had so paradoxically given it back to him?

With all his frivolity and luxury fallen from him, and with his will steeled and alert from his long life of austerity and solitude, Charles de Foucauld returned to France to enter upon the next stage of his vocation, his conversion.

He settles in Paris to write the account of his exploratory journey, and went out into the world, the world of his family. That family, profoundly Catholic in feeling, included in its large circle many wise and experienced priests and persons of culture. Gently the atmosphere touched him, and one day in the house of a relative he met the Abbé Huvelin. Of this touching and saintly figure, the influence of 'so many lives of the past and present generation, $M$. Bazin gives us a short sketch. It needs an article to itself to do it justice. Here there is room only to record that at this first meeting a warm confidence in the holy man was established in Charles de Foucauld, and shortly afterwards the Abbé Huvelin, sitting in his confessional at the Church of St. Augustin in Paris, saw the young man approach and enter.

Leaning over, without kneeling, he spoke through the grating. 202 


\section{Père de Foucauld and the Conversion of Islam}

'Father, I have no faith. I have come to you for instruction.'

The Abbé Huvelin replied, ' Kneel down and make your confession to God, and you will believe.'

'But I have not come for confession.'

'Make your confession, nevertheless,' replied the priest, and the young man knelt and confessed his sins and received absolution.

Then said the priest, 'Are you fasting?'

'Yes,' was the reply.

'Then go to communion,' commanded the priest, and so Charles de Foucauld made his communion and was reconciled to God. Henceforward every stage of his spiritual life was to be submitted to the Abbé Huvelin as his director.

Charles de Foucauld felt at once the call to the religious life. Events moved rapidly with him. After a winter spent in travelling in the Holy Land (he left a large piece of his heart in Nazareth as we shall see), he entered the novitiate at La Trappe. His habits of endurance made the austere life easy to him. 'I cannot say I have borne the rigours of cold and fasting well,' he writes, 'for I have simply not felt them.' The two frugal meals of vegetable soup of the Trappists became henceforward his rule for the rest of his life.

A saying of the Abbe Huvelin became the keynote of his spiritual development. 'Our Lord took always the lowest place and did it so completely that no one since has been able to wrest it from Him.'

The desert called him always. At the end of a year's novitiate he was transferred to a Trappist monastery in Syria, and here he was professed. But he wrote of the life: 'It is very pious, very austere and good in all ways, but be it said between you and me, it is not the utter poverty I long for, not the abjection I dream of. My desire for these is not yet satisfied.' 203 


\section{Blackfriars}

The Abbé Huvelin was still his director. De Foucauld revealed to him his desire to leave La Trappe and lead the life of a hermit at Nazareth. For five years his director withheld his consent, but finally, in 1897, he allowed him to go. But he must go alone and work out his own rule by himself. Charles had traced out a scheme for the foundation of an Order of 'Little Brothers of Jesus,' of such austerity of life as to be beyond human nature, says the Abbé Huvelin. He must renounce the idea and for himself be content to live, a hermit if he will, but at the gates of a monastery where he will be fed and cared for.

So he went first to Rome to be dispensed from his Trappist vows, and then to establish himself in a little shed in the garden of a convent of Poor Clares at Nazareth. Here he was, at last, the hermit of his dreams. Except for his books, which were his 'tools,' he possessed nothing, according to his desire, 'but what a poor workman would possess.' His days, and most of his nights, were spent in study and prayer. His happiness and joy in this life of contemplation find expression in his letters. His style is limpidly clear and direct, and gives an impression of sincerity that is not to be communicated in translation. His meditations, written during a twelve days' solitary retreat, are like a canticle of praise.

But soon his vocation carried him on. Like St. Francis of Assisi, his humility had restrained him from seeking Holy Orders, but now the Abbé Huvelin urged him to prepare for the priesthood. This fell in with Brother Charles's growing conviction that his mission was to carry the Blessed Sacrament amongst the heathen and to live in adoration himself without preaching, except by the example of love and charity. 'I saw that this divine food of which I became the minister,' he writes later, 'must be offered by me, not to my own people, but to the lame, the blind, 


\section{Père de Foucauld and the Conversion of Islam}

the poor-that is, to souls that have no priest. In my youth I travelled all through Morocco and Algeria. In Morocco, which is as big as France and has ten million inhabitants, there is not a single priest, and in the Sahara, which is seven or eight times as big as France and much more thickly populated than it was thought to be, there are only twelve missionaries. I cannot imagine a people more abandoned than this is.' Thus he wrote in 1905 .

$\mathrm{He}$ received Priest's Orders at $\mathrm{La}$ Trappe at Viviers, and said his first Mass at Notre Dame des Neiges, the monastery where he made his Trappist novitiate.

From here he made his formal request to the Bishop of the Sahara. His own words describe exactly his conception of his mission.

'I ask for two things. Firstly, permission to establish, in one of the French Garrisons that has no priest, a small public oratory with the Blessed Sacrament reserved for the sick; to live there myself and administer the Sacraments. Secondly, your authority to associate to myself there what companions, laymen or priests, our Lord may send me, and to practise with them the adoration of the Blessed Sacrament exposed on the altar.

' If you would grant me these two requests I would live there as chaplain of this humble oratory without any title either of chaplain or vicar and without stipend, as a monk following the rule of St. Augustine with or without companions, leading a life of prayer and poverty, of work and charity, not preaching, never going out except to administer the Sacraments.

'It will be a cloistered life of silence. My aim is to give spiritual help to our soldiers and to prevent the loss of their souls through lack of the last Sacraments, but above all it is to sanctify the pagan population by bringing into their midst Jesus, present in the Blessed Sacrament.'

It is this last sentence that sums up his own interpretation of his vocation. Everything in him was to be subservient to this mission of bringing that Divine Treasure of which the Catholic Church is the guardian, into the midst of the darkness of unbelief. 


\section{Blackfriars}

His director, the Abbé Huvelin, wrote his approval of the scheme to the Bishop and his belief in the fitness of 'Frère Charles' for the task. He described him as 'full of enthusiasm tempered with wisdom, loving austerity of life but allowing himself to be directed, full of zeal but ready for obedience-his love of mortification is as great as his love of God. I have watched the growth of this vocation,' said the director. 'It has always drawn him towards the Mussulmans. The years spent in travel in the Sahara have hardened him for the life, and he has grown humbler, simpler and more submissive as his vocation has devoloped. You will find in him a love of silence, of hidden activity and a firm purpose to go all lengths in love and devotion.'

So at the end of the year Igo I we see Brother Charles of Jesus, set forth into the wilderness. For equipment he packed into a small hand-barrow a Mass set and things necessary for a chapel, a few books, fifty yards of cord, a small bucket for drawing water from the wells of the desert, and some strong sailcloth to make his tent. With these few possessions he crosses the sea and is at last in his beloved Africa, with faculties and permission to begin his solitary work of evangelization.

Beni-Abbes was his first destination-a smail garrisoned post on the edge of the Sahara. Brother Charles had chosen it because of its isolation and because no priest's ministrations had as yet ever reached it. He chose it also because of its being near to Morocco, to which his eyes always turned as the scene of his future labours. Here he built his chapel and his hermitage; the roughest and most primitive building, stones and palm trunks held together with rough cement made the walls, palm leaves covered the roof and a green awning stretched over kept it all dry. His hermitage was even more primi206 


\section{Père de Foucauld and the Conversion of Islam}

tive. He slept in the sacristy, which was so small that he could not stretch himself at full length, and to the officer who condoled with him he said, 'But our Lord was cramped on the Cross.' He made an enclosure for his hermitage-a ring of stones, and within this boundary he enclosed himself. The garrison welcomed him and his administration, the soldiers worked for him; the officers fraternized and appreciated his comradeship as an old soldier and a man of culture.

Simple as the hermitage was, it was designed for more than one hermit, for Brother Charles always hoped companions would join him in the work of conversion. He laboured, prayed and watched, made himself beloved and revered by the Arabs as well as the soldiers of the garrison and by all who passed by. But though two White Fathers on the Algerian Mission thought of joining him, and a young Trappist lay-brother did actually join him, the life he offered was too austere both mentally and physically, and with the best will in the world their purpose broke down under it.

In 1903 Commandant Laperrine, the great African soldier, took him on a tour of inspection, in which he penetrated into the Hoggar, a land lying in a plateau in the farthest fastnesses of the desert, the stronghold of the Touaregs.

The Touaregs are a tribe apart from the Arabs. Originally they were white; they are wild, nomad and intractable, and never mingle with other tribes. The same terror of their warrior deeds, their raids and piracy was nurtured in the minds of the first colonisers of the desert as of the Redskins amongst the pioneers of America. This tribe, already conquered some years, the Commandant Laperrine designed to visit, making known to them his wise and beneficent sway as the military representative of France. The Père 


\section{Blackfriars}

de Foucauld, his friend in youth as an officer, would help him in his pacific mission.

In 1905 the General asked Frère Charles to establish himself in a hermitage at Tamanrasset in the heart of the Hoggar.

'What faith and what moral force did he possess to undertake such a task!' cries M. Bazin. 'Not one man of his own race or civilization was within reach, no help at hand either to body or soul. Further, no hope of winning over a people who would only be capable after years and years of educating and civilizing to understand his mission. He knew for certainty that he must die without seeing any result of his labours, that is, without reconciling one single soul to the scheme of salvation and to Christian civilization. And yet he must never doubt or hesitate, but offer himself resolutely to fulfil a task which had not one human attraction to offer-he must break with all that he loved on earth, and with the spirit of Europe in order to win the capricious, uncertain, reluctant confidence of a few wandering shepherds of the desert, of pirates living on pillage and of wretched negro slaves. This is the life that the Père de Foucauld chose to live. Most men, however strong in will, must have succumbed to one of two temptations in such a life: discouragement or demoralization. $\mathrm{He}$ remained unstained: he studied that science of sacrifice, the longest of all studies and one whose mastery is never sure. He served France faithfully in that he stood for her, and in him was seen her Faith; he rendered great service to Science; he prepared a nation for the missionaries to come after him; he sowed in solitude and his steps no one counted. $\mathrm{He}$ himself could not measure his own work.'

We have a portrait of him at this period of his life, an amateur photograph. The hermit has come out of his little hermitage and stands in the sunshine under 208 


\section{Père de Foucauld and the Conversion of Islam}

the rough sloping roof of his verandah or cloister. He wears a white habit with a strap round his waist, and a rosary hangs from it. On the breast of his scapular is embroidered a heart surmounted by the Cross. Sandals are on his feet. His hair is cropped and he has a short black beard. His attitude is entirely without self-consciousness. His hands and arms fall simply at his sides. The head leans a little to the left. He is smiling and his eyes, deep-set and very keen, are smiling too. His short figure is full of vigour and very French. It is as though he had just stepped out into the sunshine from a life of great activity within to give a glance of kindness and sympathy to his photographer.

Side by side with his spiritual task the Père de Foucauld laboured at another-the preparation of a dictionary and grammar of the Touareg dialect, together with a collection of native songs and folk-lore. This was an arduous and exacting labour that lasted into the last months of his life. It will be easily understood what a valuable guide this summary of the language will be to any who have the heroism to follow in his footsteps. It is only one instance of the hidden nature of his life that he resolutely refused to let his name appear as the author of these works when they were published.

At the beginning of his life of solitude he had the great trial to bear of being often unable to say his Mass for want of a witness, but later dispensation was obtained from Rome, and he had the consolation of being able to say his Mass every day.

Very soon his influence began to be felt-the Marabout, holy man, he was called by the Touaregs around him. He won their confidence, their reverence; he became the arbitrator in their quarrels. Year after year, in patient adoration of the Blessed Sacrament, he worked for their salvation, convinced of his voca- 


\section{Blackfriars}

tion, that he is 'set for a sign,' and with a growing conviction that he is some day to give his life for them.

The war broke out, and in course of time the Turks, instructed by the Germans, stirred up 'Holy War' in the desert. On the morning of December ist, 19r6, Frère Charles, expecting his mail, which was due to arrive from Fort Motylinski, fifty miles away, opened his door to a company of Fellagas, a fanatical Arab tribe. He was seized and bound; a short interview took place in which Brother Charles, imitating our Lord, said not a word. It seems certain, from subsequent accounts, that it was offered him to say, in exchange for his life, the Chahada or Mussulman prayer as a sign of apostasy; but that in silence he refused. He was shot and his body thrown and hastily buried in a ditch. It was as he had long anticipated and desired. He died 'for love of God, through hatred of God' (these are his own words), for the salvation of the souls of those among whom he had chosen to live.

After three weeks spent in pursuit of the murderers a young officer came from the Fort to see what was to be done at the Hermitage. The body of the Père de Foucauld was buried with military honours on a piece of rising ground, and a great wooden cross planted on it, where it could be seen for miles around.

The hermitage had been wrecked and deserted, its contents pillaged. Turning over the débris the young Frenchman found, buried in sand, what he took to be the pyx containing the Blessed Sacrament. With deep respect he picked it up and wrapped it in a linen cloth. 'I was much distressed,' he wrote of this, 'for I felt it was not for me to carry our Lord like this.' With great reverence he placed the pyx before him on the saddle of his camel and thus he rode back the fifty miles to the Fort at the head of his escort. This 


\section{Père de Foucauld and the Conversion of Islam}

was the first procession of the Blessed Sacrament in the Sahara.

When he reached the Fort with his precious burden a consultation was held as to what was to be done with the Sacred Host. An officer remembered the Père de Foucauld himself had once said that if he was murdered, leaving the Blessed Sacrament reserved, they must do one of two things-either one of them must make an act of contrition and take the Communion himself, or the Sacred Host must be sent by the post to the White Fathers.

To this last course they could not resign themselves. One of them-a sub-lieutenant-had begun his priest's studies before doing his military service, and was known to be a devout Catholic. He was chosen to take the Communion, and his superior officer, putting gloves which had never been used on his hands, opened the pyx and, after the two young men had adored the Blessed Sacrament, the younger consumed the Host.

What a touching picture is this-typical of God's methods throughout the life of Père de Foucauld. The Hidden Godhead in the desert using methods abject and putting Himself at the mercy of the goodwill of those who should be his staunch friends, bút who have left Him out in their designs of conquest.

The French did not bring Him with them as their King in their conquest of the Sahara as they did in the days of St. Louis and the Crusades. $\mathrm{He}$ is content to wait the harvest of seeds sown by such a sower as Charles de Foucauld-seed watered, as it was in the early Christian days, by a martyr's blood.

'We French,' wrote the Père de Foucauld in $19 \mathrm{I}_{3}$, ' have two essential duties to fulfil. The first is the administration and civilization of our North-West African domains, Algeria, Morocco, Tunis, the Sahara and the Soudan-an immense Empire, united 


\section{Blackfriars}

for the first time. How are we to attach this Empire to our civilization? Firstly, by working for the moral and intellectual education of its inhabitants to the utmost of our powers. The natives of our African Empire are of very diverse character. Some, the Berbers, for instance, will respond quickly to our civilization, but others, the Arabs, are much slower to respond to progress, and the negroes are again different. But all are capable of improvement.

Secondly, by evangelizing our colonies. What do we do towards this? Hardly anything. In the whole of Africa the only priests are the White Fathers, and of them there are only fifty-six in North Africa and eleven in the Sahara. This is a situation that it is the business of French Catholics to remedy. We need good priests, not to preach, but to live amongst the people, make themselves beloved and inspire confidence, respect, friendship. Then we need lay workers, men and women, to fulfil the same objectthey can enter more closely into the lives of the people and go where the priest cannot go; they can give an example of Catholic family life, the Christian spirit. We need nuns to nurse the sick and bring up the children. They must mingle with the population, living in twos and threes wherever there is a priest and a few Catholics. It will be slow work (de longue haleine), but under these conditions at the end of a certain time,- - twenty-five, fifty, a hundred yearsconversions will follow in due course, like fruit ripening as the education spreads. But if these unhappy Mussulmans never see a priest, if the only Christians they know are unjust, tyrannical, exploiters, whose only example is one of vice, how are they to be converted?'

The Père de Foucauld, on three short visits to France in 1909,1913 and 1916 , founded under the protection of the Bishop of Viviers an association for 


\section{Père de Foucauld and the Conversion of Islam}

the 'Development of the Missionary Spirit, especially in the French Colonies.' 'After the war,' he wrote to a friend, 'I shall do all I can to establish the Association, travelling and staying in France for this purpose. But the will of God be done in this as in all things.' As we have seen, the Will of God was accomplished differently. But the Association in its initial stages exists. Two main ideas inspire it. The first is that a vigorous effort is needed to-day towards the conversion of the heathen, and that the French are guilty of grave neglect of the evangelization of 'our brothers, the Mussulmans under the dominion of France.' The second is that this hard task will not be accomplished by collecting funds and saying a few prayers. A missionary spirit must be created and fostered. This must be attained by a strenuously Catholic life in individuals, which will nourish the idea and fulfil it in action. And the means of attaining to this sincere Catholic life, fruitful in faith and action, is the uniting the members of an Association under a rule.

Such an Association exists under the name of the Association Foucauld, and has its Secretarial office at 3o Rue Lhomond, Paris V.

(Mrs.) Reginald Balfour. 